\title{
Otomatisasi Sistem Penerangan dan Penyejuk Ruangan Kantor
}

\section{(Studi Kasus : Laboratorium Otomasi Industri Teknik Elektro)}

\author{
Reza Aditya Nugroho ${ }^{1}$, Juli Sardi² \\ 1,2Universitas Negeri Padang \\ Jl. Prof Dr. Hamka Air Tawar, Padang \\ rezaadityanugroho.98@gmail.com ${ }^{1}$,JuliSardi@ft.unp.ac.id ${ }^{2}$
}

\begin{abstract}
Office lights and air conditioners are one of the biggest contributors to the use of electrical energy. The use of inefficient lights and air conditioning causes a waste of electricity which results in expensive electricity bills. This study aims to automate the lighting and air conditioning systems of the office. The method used is the design and manufacture of hardware and software.Hardware in the form of a panel consisting of Arduino Uno which is the control center for the tool, ssr relay driver functions as a switch on lights and ac, Infrared sensors are used as detectionfor counting the number of people entering and leaving the room which is the basis for automating the life of lighting and air conditioning in the office. Lcd is used for monitoring the status of the counter detected by the infrared sensor.The software used is the Arduino IDE which can control input and output processes. The results show that this tool is able to work in accordance with the desired and expected goals. This system can be applied and used in the process of automating lighting and air conditioning offices.
\end{abstract}

Keywords-system, LCD, arduino uno, infrared sensor and relays.

Abstrak- Lampu dan AC perkantoran merupakan salah satu penyumbang terbesar dalam pemakaian energi listrik. Penggunaan lampu dan ac yang tidak efisien menimbulkan pemborosan listrik yang mengakibatkan tagihan listrik mahal. Penelitian ini bertujuan untuk membuat otomatisasi pada sistem penerangan dan penyejuk ruangan kantor. Metode yang digunakan adalah perancangan dan pembuatan hardware dan software. Hardware berupa panel yang terdiri dari arduino uno yang merupakan pusat kendali alat, driver relay ssr berfungsi sebagai saklar pada lampu dan ac, sensor infrared sebagai pendeteksi untuk menghitung jumlah orang yang masuk dan keluar ruangan yang menjadi dasar untuk mengotomatisasi hidupnya penerangan dan penyejuk ruangan kantor. Lcd digunakan untuk monitoring status counter yang terdeteksi oleh sensor infrared. Software yang digunakan adalah arduino IDE yang dapat mengontrol proses input dan output. Setelah dilakukan pengujian terhadap sistem yang telah dibuat, didapatkan hasil bahwa alat ini mampu bekerja sesuai dengan tujuan yang di inginkan dan di harapkan. Sistem ini bisa di terapkan dan digunakan dalam proses otomatisasi penerangan dan penyejuk ruangan kantor.

Kata kunci-sistem, LCD, arduino uno, sensor infrared dan relay.

\section{Pendahuluan}

Energi listrik saat sekarang ini merupakan energi yang sangat dibutuhkan. Energi listrik memegang peranan penting dalam pengembangan dan pembangunan ekonomi seiring dengan berlangsunya pertumbuhan ekonomi nasional. Kebutuhan energi listrik semakin lama semakin meningkat, sementara persediaan pasokan listrik terbatas, hal ini menuntut kita untuk selalu menghemat dalam menggunakan energi listrik[1]. Pengendalian alat-alat listrik khususnya lampu dan AC adalah hal yang penting dalam pengelolaan energi listrik pada suatu tempat, misalnya pada gedung perkantoran yang mempunyai banyak lampu dan AC di setiap ruangan. Namun, sampai sekarang ini masih banyak di jumpai penggunaan lampu dan AC masih dikontrol oleh manusia secara manual dengan menggunakan saklar yang tersedia pada masingmasing panel ruangan. Pemborosan energi listrik sering kali terjadi karena pegawai lupa mematikan lampu dan AC pada sebuah ruangan pada saat selesai bekerja yang mengakibatkan penggunaan energi listrik masih belum selaras dengan tingkat efesiensi penggunaan energi listrik saat sekarang ini[2][3].

Salah satu cara yang bisa dilakukan dalam menyelesaikan permasalahan tersebut adalah dengan membuat dan menciptakan sistem otomatisasi yang dapat diaplikasikan pada lampu dan AC diruangan.

Sebelumnya sudah ada beberapa penelitian yang berkaitan dengan otomatisasi lampu dan peralatan listrik lainnya menggunakan Voice Recognition dan Android yang dibuat secara prototype dan menggunakan modul berupa GSM sim 800L yang mengharuskan kita untuk mempunyai pulsa untuk melakukan pengontrolan secara otomatis[4]. Selain itu juga terdapat penelitian tentang rancang bangun smarthome menggunakan suara dengan easy voice recognition yang dibuat secara prototype dan menggunakan modul easy VR sebagai perintah suara untuk mematikan dan menghidupkan lampu dan kipas angin, selain itu modul easy $V R$ cukup memberatkan karena 
memiliki harga yang mahal dan tingkat kesulitan yang tinggi[5].

Berdasarakan penelitian diatas penulis berinovasi untuk membuat alat yang bisa mengontrol otomatisasi penerangan dan penyejuk ruangan kantor berdasarkan jumlah orang yang terdeteksi oleh sensor infra red. Pada sistem ini sensor infrared digunakan sebagai counter up atau counter down yang berfungsi untuk menghitung jumlah orang yang masuk dan keluar dari ruangan. Alat ini menggunakan lcd yang dapat memonitoring jumlah status counter yang terbaca oleh sistem.

\section{Metode}

Metode yang digunakan dalam penelitian ini adalah membuat perangkat hardware berupa panel serta pelaksanaan percobaan pengujian pada masing-masing komponen.

\section{A. Blok Diagram}

Secara keseluruhan perancangan dapat di jelaskan pada gambar 1

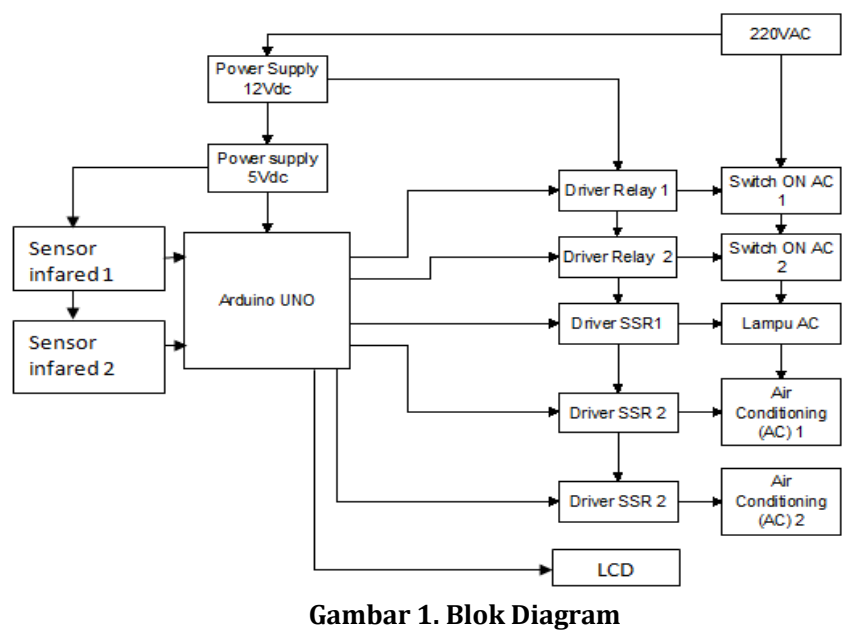

Berdasarkan blok diagram 1 di atas terdiri dari arduino uno sebagai pusat kendali alat. Sensor infrared 1 digunakan untuk mendeteksi orang yang akan keluar dari ruangan, sedangkan sensor infrared 2 digunakan untuk mendeteksi orang yang masuk ke dalam ruangan. Driver relay 1 dan 2 digunakan switch pada ac1 dan ac2. Sedangkan driver SSR digunakan untuk saklar lampu, ac1 dan ac2. Lcd pada alat ini di gunakan untuk memonitoring jumlah orang yang masuk dan keluar dari ruangan.

\section{B. Perancangan Hardware}

Perancangan hardware adalah bagian yang penting dalam tugas akhir ini. Dengan adanya hardware berupa panel penulis dapat menguji secara real apakah alat ini dapat berfungsi dengan baik atau tidak. Panel yang digunakan berupa akrilik dengan tebal $2 \mathrm{~mm}$.

1. Perancangan mekanikal
Merupakan bentuk dari alat keseluruhan yang dimana bentuk alat keseluruhan dapat di lihat pada gambar 2 dibawah ini.

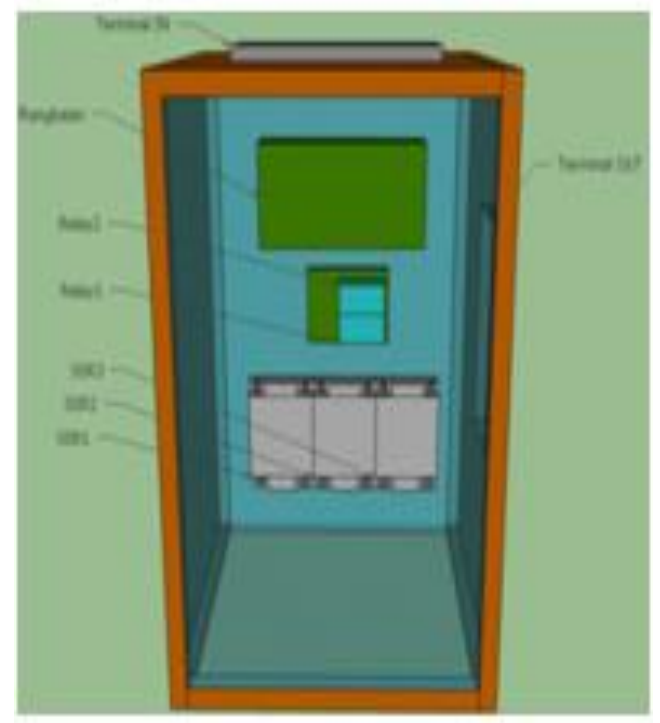

Gambar 2. Bentuk perancangan alat

2. Arduino Uno sebagai pusat dari kendali alat berdasarkan input yang diberikan.

3. Sensor infrared berfungsi sebagai pendeteksi orang yang akan masuk dan keluar dari ruangan.

4. Solid stated relay (SSR) berfungsi sebagai saklar yang akan menghidupkan atau mematikan lampu dan ac secara oromatis.

5. Perancangan keseluruhan

Rancangan keseluruhan yang terdiri dari arduino uno, solid stated relay, sensor infrared, dan lcd dapat di lihat pada gambar 3 di bawah.

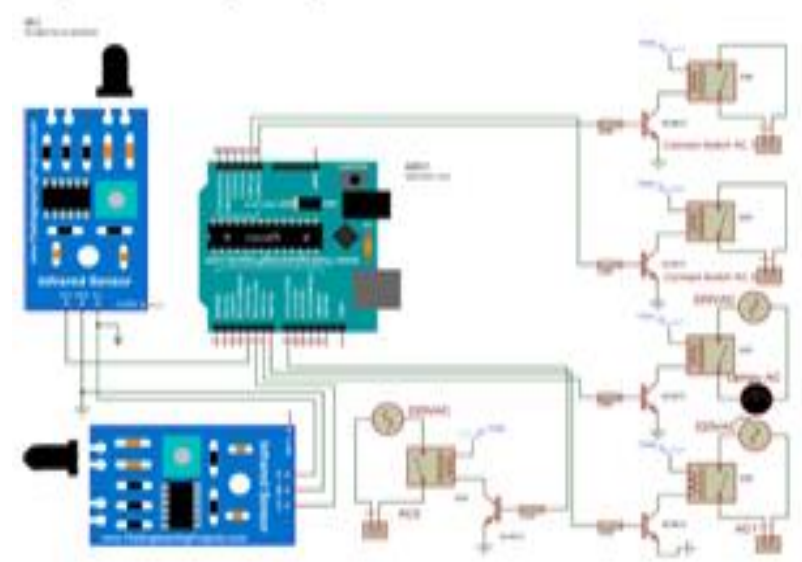

Gambar 3. Rangkaian keseluruhan

\section{Perancangan Software}

Pada tugas akhir ini perlu adanya perancangan software secara keseluruhan menggunakan arduino ide yang merupakan software bawaan dari arduino uno itu sendiri. Arduino dapat mengedalikan proses input dan output yang di gunakan pada alat otomatisasi lampu dan ac di ruangan laboratorium otomasi industri ini. Kode 
pemograman yang di gunakan pada arduino ini adalah bahasa C. Pada arduino ide dapat melakukan proses compile dan upload program yang akan di buat dan di jalankan. Untuk memberi infromasi antara perangkat dan pengguna, penulis memberi input untuk mengatur ototmatisasi lampu dan ac di ruangan secara otomatis.

\section{HASIL DAN PEMBAHASAN}

Pada bagian ini untuk dapat membuktikan apakah alat dapat berfungsi dengan baik atau tidak maka di perlukan pengujian terhadap alat tersebut. Adapun pengujian yang dilakukan terhadap sensor infra red, apakah sensor berfungsi dengan baik atau tidak dalam proses mendeteksi adanya halangan.

Proses pengujian alat di lakukan dengan langkah pertama yaitu mendeteksi orang yang akan masuk ke dalam ruangan. Ketika orang masuk ke dalam ruangan maka sensor 1 akan mendeteksi adanya halangan terlebih dahulu. Setelah itu sensor 2 yang ada di dalam ruangan akan mendeteksi adanya halangan dan sistem akan mengcounter up menjadi +1 . Pada saat proses counter up terjadi maka akan tampil pada lcd di panel. Adapun pengujian yang penulis lakukan sebagai berikut:
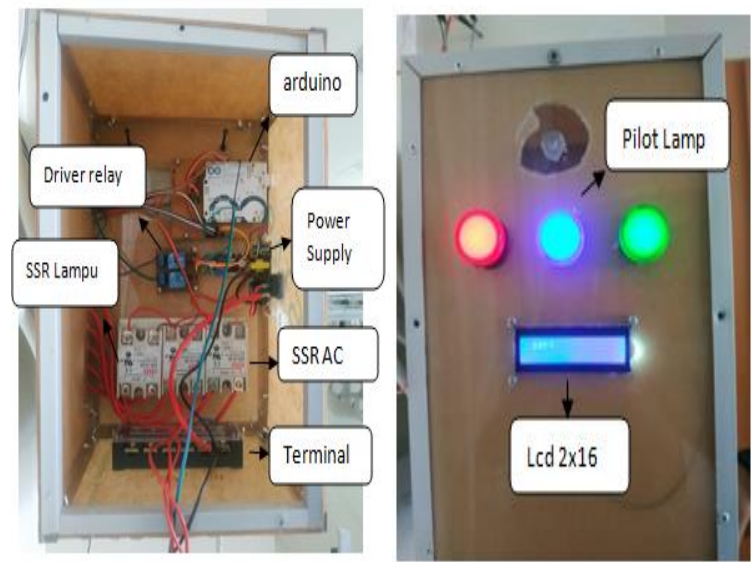

Gambar 4. Bentuk panel

\section{A. Pengujian Hardware}

1. Pengujian sensor infared sebagai counter up

Hasil pengujian sensor infrared sebagai counter up dapat dilihat pada tabel di bawah

\begin{tabular}{|l|c|c|c|c|}
\hline No & Sensor 1 & Sensor 2 & $\begin{array}{c}\text { Jumlah orang } \\
\text { masuk }\end{array}$ & $\begin{array}{c}\text { Status } \\
\text { Counter }\end{array}$ \\
\hline 1 & Terdeteksi & Terdeteksi & 1 & 1 \\
\hline 2 & Terdeteksi & $\begin{array}{c}\text { Tidak } \\
\text { Terdeteksi }\end{array}$ & 1 & 1 \\
\hline 3 & Terdeteksi & Terdeteksi & 2 & 2 \\
\hline 4 & Terdeteksi & $\begin{array}{c}\text { Tidak } \\
\text { Terdeteksi }\end{array}$ & 2 & 3 \\
\hline 5 & Terdeteksi & Terdeteksi & 3 & 3 \\
\hline 6 & Terdeteksi & $\begin{array}{c}\text { Tidak } \\
\text { Terdeteksi }\end{array}$ & 3 & \\
\hline
\end{tabular}

Tabel 1. Pengujian sensor infrared sebagai counter up
Berdasarkan tabel di atas, pada saat orang pertama masuk kedalam ruangan dan melewati sensor 1 dan sensor 2 status counter up akan berubah menjadi +1 . Selanjutnya dilakukan pengujian kepada orang kedua hanya melewati sensor 1 dan tidak melewati sensor 2 maka proses counter up tidak terjadi. Hal ini dikarenakan sensor 2 tidak terdeteksi oleh halangan dan proses counter up tidak berubah. Lalu penulis melakukan pengujian kepada orang ketiga dengan melewati sensor 1 dan sensor 2, maka status counter up akan bertambah 1. Proses ini akan terus berlanjut seperti yang di tunjukan pada tabel diatas. Jadi prinsip sensor infra red sebagai counter up ini akan terjadi jika sensor 1 di luar pintu harus terdeteksi adanya halangan terlebih dahulu lalu sistem akan memberikan sinyal kepada arduino sampai melewati sensor 2 yang ada di dalam ruangan. Pada saat sensor 2 telah terdeteksi adanya halangan maka status counter up akan bertambah. Apabila sensor 2 tidak terdeteksi adanya halangan maka proses counter up tidak akan terjadi.

\section{Pengujian sensor infrared sebagai counter down}

Hasil pengujian sensor infrared sebagai counter down dapat dilihat pada tabel di bawah:

\begin{tabular}{|l|c|c|c|c|}
\hline No & Sensor 2 & Sensor 1 & $\begin{array}{c}\text { Jumlah orang } \\
\text { masuk }\end{array}$ & $\begin{array}{c}\text { Status } \\
\text { Counter }\end{array}$ \\
\hline 1 & Terdeteksi & Terdeteksi & 1 & 2 \\
\hline 2 & Terdeteksi & $\begin{array}{c}\text { Tidak } \\
\text { Terdeteksi }\end{array}$ & 1 & 2 \\
\hline 3 & Terdeteksi & Terdeteksi & 2 & 1 \\
\hline 4 & Terdeteksi & $\begin{array}{c}\text { Tidak } \\
\text { Terdeteksi }\end{array}$ & 2 & 0 \\
\hline 5 & Terdeteksi & Terdeteksi & 3 & 0 \\
\hline 6 & Terdeteksi & $\begin{array}{c}\text { Tidak } \\
\text { Terdeteksi }\end{array}$ & 3 & \\
\hline
\end{tabular}

Berdasarkan tabel 2 diatas, dapat di lihat bahwa pada pengujian orang pertama, ketika orang tersebut keluar melewati sensor 2 terlebih dahulu,selanjutnya melewati sensor 1 maka system akan menghitung mundur dan status counter berubah menjadi 2. Selanjutnya dilakukan pengujian kepada orang kedua dengan cara hanya melewati sensor 2 dan tidak melewati sensor 1, selanjutnya hasil yang di dapat status counter tidak menghitung mundur. Hal ini di karenakan hanya sensor 2 yang terdeteksi sementara sensor 1 nya tidak terdeteksi oleh halangan. Syarat untuk sistem dapat melakukan counter down atau menghitung mundur orang yang akan keluar dari ruangan harus melewati sensor 2 yang ada di dalam ruangan, setelah itu orang tersebut harus melewati sensor 1 di luar pintu yang akan membuat sistem menghitung mundur jumlah orang yang akan keluar dari ruangan. 


\section{Pengujian Solid stated Relay}

Hasil pengujian solid stated relay dapat di lihat pada tabel di bawah ini

\begin{tabular}{|l|l|l|c|c|c|c|}
\hline No & Sensor 1 & Sensor 2 & $\begin{array}{c}\text { Jumlah } \\
\text { Orang }\end{array}$ & $\begin{array}{c}\text { Status } \\
\text { Counter }\end{array}$ & $\begin{array}{c}\text { Relay } \\
\text { Lampu } \\
\text { dan Ac1 }\end{array}$ & $\begin{array}{c}\text { Relay } \\
\text { Ac 2 }\end{array}$ \\
\hline 1 & Terdeteksi & Terdeteksi & 1 & 1 & On & Off \\
\hline 2 & Terdeteksi & Terdeteksi & 2 & 2 & On & Off \\
\hline 3 & Terdeteksi & Terdeteksi & 3 & 3 & On & Off \\
\hline 4 & Terdeteksi & Terdeteksi & 4 & 4 & On & Off \\
\hline 5 & Terdeteksi & Terdeteksi & 5 & 5 & On & On \\
\hline 6 & Terdeteksi & Terdeteksi & 6 & 6 & On & On \\
\hline 7 & Terdeteksi & Terdeteksi & 7 & 7 & On & On \\
\hline
\end{tabular}

Dari hasil tabel di atas dapat di lihat bahwa pada saat orang yang masuk sebanyak 1-4 ke dalam ruangan maka kondisi SSR lampu dan SSR Ac1 akan aktif, sehingga lampu dan Ac 1 yang ada di ruangan akan menyala secara otomatis. Selanjutnya pada saat orang yang terhitung masuk $>=5$ maka kontak pada SSR Ac 2 akan aktif dan AC 2 yang ada di ruangan akan menyala. Pengukuran rangkaian lampu AC dapat diketahui bahwa, relay aktif, maka pada pin relay terukur tegangan sebesar 220 Vac, dan jika kondisi relay mati maka tegangan terukur 0 Vac .

4. Pengujian alat secara keseluruhan

a) Hasil pengujian orang masuk ke dalam ruangan

Hasil pengujian alat secara keseluruhan ketika orang akan masuk ke dalam ruangan di ambil 5 orang sebagai sample pengujian dapat di lihat pada tabel di bawah ini:

\begin{tabular}{|l|c|c|c|c|c|c|}
\hline No & $\begin{array}{c}\text { Sensor } \\
1\end{array}$ & $\begin{array}{c}\text { Sensor } \\
2\end{array}$ & $\begin{array}{c}\text { Status } \\
\text { Counter }\end{array}$ & $\begin{array}{c}\text { Lampu } \\
\text { dan Ac1 }\end{array}$ & $\begin{array}{c}\text { Ac } \\
2\end{array}$ & Keterangan \\
\hline 1 & $\begin{array}{c}\text { Terdet } \\
\text { eksi }\end{array}$ & $\begin{array}{c}\text { Terdet } \\
\text { eksi }\end{array}$ & 1 & On & Off & $\begin{array}{c}\text { Lampu dan } \\
\text { Ac1 aktif }\end{array}$ \\
\hline 2. & $\begin{array}{c}\text { Terdet } \\
\text { eksi }\end{array}$ & $\begin{array}{c}\text { Terdet } \\
\text { eksi }\end{array}$ & 2 & On & Off & $\begin{array}{c}\text { Lampu dan } \\
\text { Ac1 aktif }\end{array}$ \\
\hline 3. & $\begin{array}{c}\text { Terdet } \\
\text { eksi }\end{array}$ & $\begin{array}{c}\text { Terdet } \\
\text { eksi }\end{array}$ & 3 & On & Off & $\begin{array}{c}\text { Lampu dan } \\
\text { Ac1 aktif }\end{array}$ \\
\hline 4. & $\begin{array}{c}\text { Terdet } \\
\text { eksi }\end{array}$ & $\begin{array}{c}\text { Terdet } \\
\text { eksi }\end{array}$ & 4 & On & Off & $\begin{array}{c}\text { Lampu dan } \\
\text { Ac1 aktif }\end{array}$ \\
\hline 5. & $\begin{array}{c}\text { Terdet } \\
\text { eksi }\end{array}$ & $\begin{array}{c}\text { Terdet } \\
\text { eksi }\end{array}$ & 5 & On & On & $\begin{array}{c}\text { Lampu, Ac1 } \\
\text { dan Ac2 } \\
\text { aktif }\end{array}$ \\
\hline
\end{tabular}

Tabel 4. Pengujian ketika masuk ke ruangan
Pada tabel diatas, dapat di lihat ketika 1 orang masuk ke dalam ruangan melewati sensor 1 dan sensor 2 , maka status counter berubah menjadi 1. Selanjutnya arduino akan mengirim sinyal ke SSR lampu dan SSR Ac1. Maka SSR lampu dan SSR AC 1 akan aktif yang menghasilkan output berupa aktivasi lampu dan AC1 dalam ruangan menyala secara otomatis. Hal ini di karenakan program yang di atur akan mengaktifkan lampu dan Ac 1 ketika satu orang terdeteksi masuk ke dalam ruangan. Pada saat sistem meng-counter $>=5$ maka relay SSR AC2 akan aktif dan menyalakan AC2 di ruangan secara otomatis.

b) Hasil pengujian orang keluar dari ruangan

Hasil pengujian alat keseluruhan ketika orang akan keluar dari ruangan di ambil sample kepada 5 orang yang masuk tadi dapat di lihat data nya pada tabel di bawah ini.

\begin{tabular}{|c|c|c|c|c|c|c|}
\hline No & $\begin{array}{c}\text { Sensor } \\
2\end{array}$ & $\begin{array}{c}\text { Sensor } \\
1\end{array}$ & $\begin{array}{c}\text { Status } \\
\text { Counter }\end{array}$ & $\begin{array}{l}\text { Lampu } \\
\text { dan Ac1 }\end{array}$ & $\begin{array}{c}\text { Ac } \\
2\end{array}$ & Keterangan \\
\hline 1 & $\begin{array}{c}\text { Terdet } \\
\text { eksi }\end{array}$ & $\begin{array}{c}\text { Terdete } \\
\text { ksi }\end{array}$ & 6 & On & On & $\begin{array}{c}\text { Lampu, Ac1 } \\
\text { dan Ac2 aktif }\end{array}$ \\
\hline 2. & $\begin{array}{c}\text { Terdet } \\
\text { eksi }\end{array}$ & $\begin{array}{c}\text { Terdete } \\
\text { ksi }\end{array}$ & 5 & On & On & $\begin{array}{c}\text { Lampu, Ac1 } \\
\text { dan Ac2 aktif }\end{array}$ \\
\hline 3. & $\begin{array}{c}\text { Terdet } \\
\text { eksi }\end{array}$ & $\begin{array}{c}\text { Terdete } \\
\text { ksi }\end{array}$ & 4 & On & Off & $\begin{array}{c}\text { Lampu, Ac1 } \\
\text { aktif dan Ac2 } \\
\text { mati }\end{array}$ \\
\hline 4. & $\begin{array}{c}\text { Terdet } \\
\text { eksi }\end{array}$ & $\begin{array}{c}\text { Terdete } \\
\text { ksi }\end{array}$ & 3 & On & Off & $\begin{array}{c}\text { Lampu, Ac1 } \\
\text { aktif dan Ac2 } \\
\text { mati }\end{array}$ \\
\hline 5. & $\begin{array}{c}\text { Terdet } \\
\text { eksi }\end{array}$ & $\begin{array}{c}\text { Terdete } \\
\text { ksi }\end{array}$ & 2 & On & Off & $\begin{array}{c}\text { Lampu, Ac1 } \\
\text { aktif dan Ac2 } \\
\text { mati }\end{array}$ \\
\hline
\end{tabular}

Tabel 5. Pengujian ketika keluar dari ruangan

Berdasarkan tabel di atas, dapat diliat pada saat 3 orang yang keluar dari ruangan dan status counter menjadi 4 maka Ac 2 akan mati secara otomatis. Hal ini karna program yang di atur akan mematikan Ac 2 ketika jumlah counter terhitung $<5$. Selanjutnya pada saat status counter menjadi 0 dan itu menandakan bahwa sudah tidak ada orang di ruangan maka sistem akan mematikan lampu dan Ac 1 secara otomatis.

\section{B. Pengujian Software}

Program merupakan induk sistem kendali yang akan di buat. Software dari alat ini menggunakan pemograman bahasa dan sebagai compiler dari pemograman adalah arduino. 


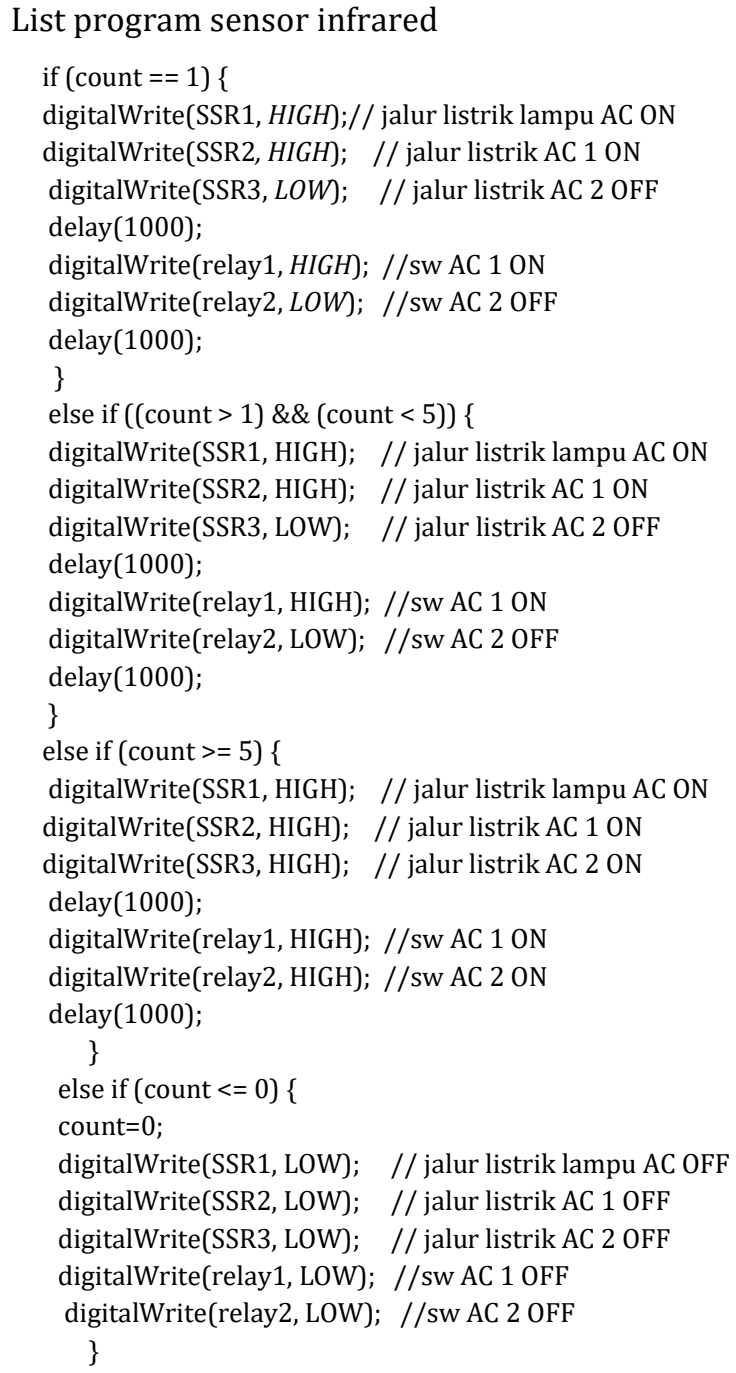

Pada list program di atas adalah untuk pembacaan dari sensor 1 dan sensor 2 pada saat terdeteksi halangan hingga ter-counter up 1 hingga lebih dari 5. Pada saat counter terjadi dengan jumlah orang yang masuk ke ruangan berjumlah 1 maka arduino akan mengirim sinyal ke SSR untuk mengaktifkan kontak pada SSR lampu dan SSR Ac 1. Ketika kontak pada SSR lampu dan Ac 1 telah aktif maka lampu dan Ac1 pada ruangan akan aktif secara otomatis. Pada saat counter up terjadi hingga 5 kali maka proses akitvasi kontak SSR Ac 2 akan aktif. Selanjutnya pada saat orang keluar dari ruangan maka proses counter down terjadi ketika sensor 2 dan sensor 1 terdeteksi oleh halangan, lalu sistem menghitung $<5$ maka kontak relay SSR AC2 akan mati. Pada saat sistem counter down terhitung $<1$ maka kontak pada relay SSR lampu dan AC 1 akan mati.

\section{PENUTUP}

Berdasarkan dari pengujian hardware dan software pada alat otomatisasi dan monitoring ruangan labor otomasi industri sudah bekerja dengan baik dan bekerja sesuai dengan yang di harapkan. Yang dimana pembacaan sensor infrared sebagai counter up dan counter down sudah sesuai dengan yang di inginkan. Dengan pengujian yang di sudah di lakukan, alat dapat berfungsi dengan sangat baik.

\section{REFERENSI}

[1] T. M. Arif Setiawan, P. Susetyo W, Budi Nur Iman, "Rancang Bangun Sistem Otomatisasi Rumah Berbasis Mikrokontroler," Ranc. Bangun Sist. Otomatisasi Rumah Berbas. Mikrokontroler, 2013.

[2] R. D. Risanty and L. Arianto, "Rancang Bangun Sistem Pengendalian Listrik Ruangan Dengan Menggunakan Atmega 328 Dan Sms Gateway Sebagai Media Informasi," J. Sist. Inf., 2015.

[3] S. Hasan, M. Rakhman, and A. Maulana, "'Audit Energi Untuk Pemakaian Air Conditioning (AC) Pada Gedung Perkantoran dan Ruang Kuliah di UPI,"' Artik. Audit Energi, 2013.

[4] I. Fachri Rizal, I. W. A. Arimbawa, and R. Afwani, "Rancang Bangun Digital Home Assistant Dengan Perintah Suara Menggunakan Raspberry Pi Dan Smart Phone," J. Comput. Sci. Informatics Eng., 2018, doi: $10.29303 /$ jcosine.v2i 2.84

[5] W. Lidiawati, L. M. Pratomo, W. -, and J. Hidayat, "Otomatisasi Lampu, Tirai, dan Kipas Angin Menggunakan Mikrokontroler untuk Menghemat Energi Listrik," J. Elektron. dan Telekomun., 2016, doi: 10.14203/jet.v13.66-72.

\section{Biodata penulis}

Reza Aditya Nugroho, lahir di Padang, 28 Agustus 1998. Menyelesaikan studi DIV Teknik Elektro Industri Pada Jurusan Teknik Elektro Fakultas Teknik Universitas Negeri Padang.

Juli Sardi, S.Pd, M.T, Lahir di Dhamasraya, 18 Juli 1987 Menyelesaikan Studi S1 di Universitas Negeri Padang Tahun 2010, Pendidikan S2 di Institut Teknologi Sepuluh November Tahun 2013. Saat ini terdaftar sebagai dosen pengajar pada jurusan teknik elektro Uiniversitas Negeri Padang. 